\title{
NOTE
}

\section{VALIDATION OF PCR-RFLP TESTING METHOD TO DETECT PORCINE CONTAMINATION IN CHICKEN NUGGET}

\author{
Tri Joko Raharjo ${ }^{1,2, *}$, Winda Cahyaningtyas ${ }^{1}$, Surajiman $^{2}$, Istini $^{2}$, and Deni Pranowo ${ }^{1}$ \\ ${ }^{1}$ Department of Chemistry, Faculty of Mathematics and Natural Sciences, Universitas Gadjah Mada, \\ Sekip Utara, Yogyakarta, Indonesia, 55281 \\ ${ }^{2}$ Halal Research Group, Integrated Research and Testing Laboratory, Universitas Gadjah Mada, Yogyakarta, Indonesia
}

Received June 21, 2012; Accepted October 23, 2012

\begin{abstract}
PCR-RFLP technique to detect porcine contamination in chicken nugget has been developed and validated in this research. Various concentrations of pork were fortified during preparation of the nugget. DNA was then isolated from the nugget followed by PCR employed primers which targeted a $359 \mathrm{bp}$ cytB gene fragment of mitochondrial DNA. For RFLP, the PCR product was digested by means of BamHI and BseDI enzymes. Cutting DNA fragments from nugget containing pork using BseDI enzyme produced DNA fragment with size 228 and $131 \mathrm{bp}$, while cutting with BamHI enzyme produce DNA fragments with sizes 244 and $115 \mathrm{bp}$. All of these fragments were not present in RFLP analysis of pork-free nugget. The method shows good specificity and precision and could detect porcine contamination in the nugget up to $5 \%$. The method has been applied to test commercial nugget. Four brand of Halallabeled commercial nugget as well as four brand of non labeled one gave negative porcine contamination.
\end{abstract}

Keywords: porcine; Halal; PCR; RFLP

\section{ABSTRAK}

Teknik PCR-RFLP untuk mendeteksi kontaminasi babi di nuget ayam telah dikembangkan dan divalidasi dalam penelitian ini. Berbagai konsentrasi daging babi yang dicampurkan dalam pembuatan nuget ayam. DNA kemudian diisolasi dari nuget diikuti oleh PCR dengan primer yang menargetkan 359 pb cytB fragmen gen dari DNA mitokondria. Untuk RFLP, produk PCR dipotong dengan cara enzim BamHI dan BseDI. Pemotongan fragmen DNA dari nuget mengandung babi menggunakan BseDI enzim menghasilkan fragmen DNA dengan ukuran 228 dan 131 pb, sedangkan pemotongan dengan BamHI enzim menghasilkan fragmen DNA dengan ukuran 244 dan 115 pb. Fragmen-fragmen hasil pemotongan tersebut tidak ditemukan dalam analisis RFLP fragmen DNA hasil PCR DNA nuget tanpa daging babi. Metode ini menunjukkan spesifisitas dan presisi yang baik serta mampu mendeteksi kontaminasi babi di nugget sampai dengan 5\%. Metode ini telah diterapkan untuk menguji komersial nugget. Empat merek nugget berlabel halal dan serta empat merek tanpa label halal memberikan hasil negatif kontaminasi babi.

Kata Kunci: babi; Halal; PCR; RFLP

\section{INTRODUCTION}

The main concern in the field of food safety is determination of food authenticity (authentication) and forgery detection [1-3]. In Islam, mixing food either meat or non-meat products with other ingredients such unlawful oil and pork becomes interesting issues. Contamination of the food by porcine component could also happen accidently due to lack of information of the raw materials. Since pork contents in the food related to the halalness of the foods, both issues should be received attention during halal certification process. In Indonesia halal certification is conducted by reviewing the documents related to food production process, which

* Corresponding author. Tel/Fax : +62-274545188

Email address : trijr_mipa@ugm.ac.id could not cover the authentication of fake or pork contaminated ingredient. Laboratory test is needed in order to confirm if the food contaminated by or not.

Some methods to identify the presence of porcine contamination in processed food have been developed such as the protein analysis, detection by using DNA [4-5]. Protein analysis included SDS-PAGE [6], IEF [7], ELISA [8] and HPLC [9]. Unfortunately, the test based on protein rather difficult because of the presence of protein is always dependent on the type of the tissue of food raw materials and sensitive to heat treatment [10].

DNA-based testing is growing rapidly due to its molecular properties advantages. DNA is more stable against changes in temperature or extreme pressure.

Tri Joko Raharjo et al. 


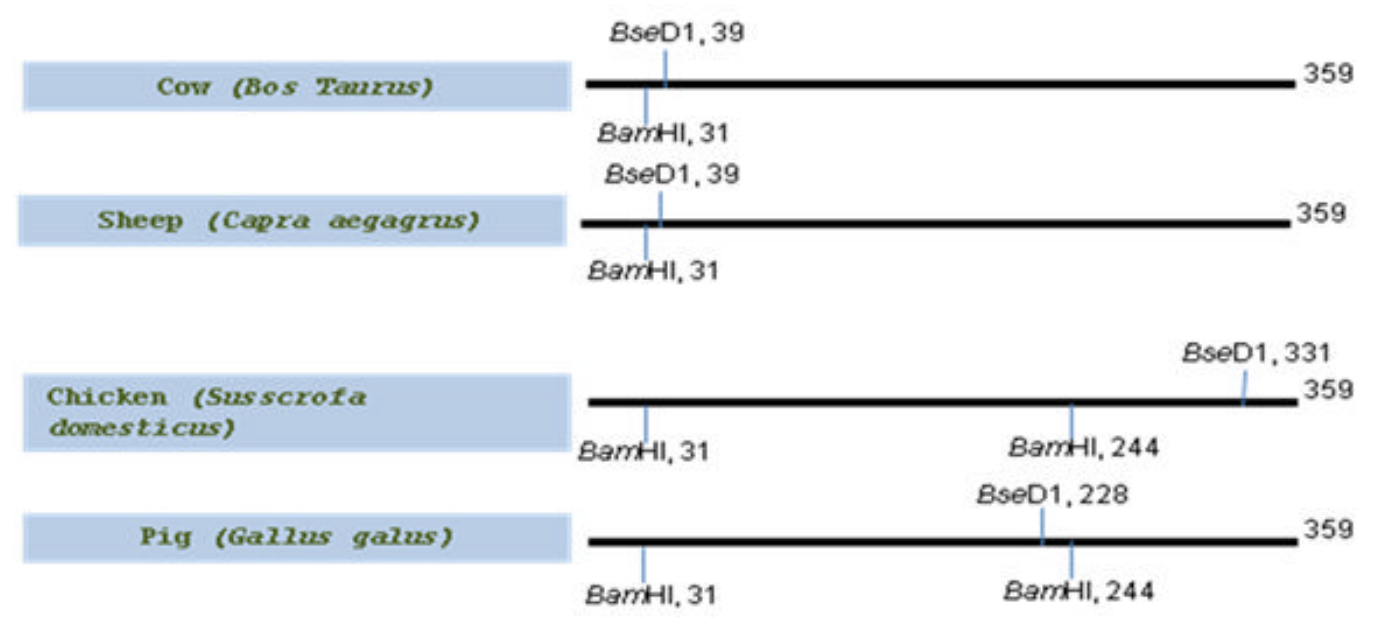

Fig 1. Comparison of BseDI and BamHI restriction map of 359 bp cytB DNA fragment from various organisms [25]

Table 1. Comparison of BseDI and BamHI fragment size of 359 bp cytB DNA fragment from various organisms [25].

\begin{tabular}{lcc}
\hline \multicolumn{1}{c}{ Organism } & BseDI (bp) & BamHI (bp) \\
\hline Cow & 320,39 & 328,31 \\
Sheep & 320,39 & 328,31 \\
Chicken & 328,31 & $213,115,31$ \\
Pig & 288,171 & $213,115,31$ \\
\hline
\end{tabular}

These methods included DNA hybridization [11], PCRRAPD [12], PCR-RFLP [13-14], species-specific PCR [15-18], real-Time PCR [19-20], PCR-based finger printing [21] and multiplex PCR [22-23].

PCR-RFLP methods are commonly targeted genes on mitochondrial DNA (mtDNA). The mtDNA is chosen due to its high number presence in the cell and possesses high rate of mutation leading to high variation among species [24]. One of the approach is amplification of gene encode cytochrome $b$ (cytB gene). One of the primer to amplify the gene is located at position 70 and 429 (starting position in gene nucleotide sequence). PCR using these primers theoretically result in $359 \mathrm{bp}$ length DNA fragments. RFLP could be performed by digestion of the PCR fragment using restriction enzymes of BamHI and BseDI followed by electrophoresis analysis. Fig. 1 show the restriction map of both enzyme for various species and the size of restriction product resumed on Table 1. Specific length of DNA fragments, 288, 171 bp for BseDI digestion and 213, 115 bp for $\mathrm{BamHI}$ digestion present only if the digested fragments are porcine DNA or contain pig DNA.

It has reported the performance this methods to detect porcine contamination in the fresh meat mixture. In case of food Raharjo et al. [25] has validated the method to test porcine contamination in meatball. The method gave good specificity, as well as very low limit detection (could detect up to $1 \%$ level of contamination).
In analytical method different sample matrix mean different performance of an analytical method. This paper reports the performance of the previous PCRRFLP methods [25] in detecting porcine contamination in other processed food, chicken nugget. This food consists of different ingredient to meatball and processed in different way which could lead to different performance of the methods. The observed performance in validation includes specificity and limit detection of the methods.

\section{EXPERIMENTAL SECTION}

\section{Materials}

Chicken and pork were purchased from traditional market in Yogyakarta. NucleoSpin $®$ Food Kits (Clontech) was employed to isolate the DNA. PCR was performed by illustra ${ }^{\mathrm{TM}}$ puReTaq Ready-To-GoPCR Beads (GE Healthcare) with primer forward (PF: 5'-CCATCAAACATTTCATCATGATGAAA-3') and primer reverse (PR:5'-GCCCCTCAGAATGATATTTGT CCTCA-3') synthesized by 1stBASE (Singapore). Enzymes BseDI and BamHI were obtained from Fermentas.

\section{Instrumentation}

PCR was performed by thermalcycler machine Genecycler 10432 (Biorad). Electrophoresis apparatus for gel agarose was used to analyses RFLP.

\section{Procedure}

\section{Isolation of DNA from chicken nugget}

The nugget with various concentration of pork was prepared in accordance with common cooking recipes. DNA was isolated according to Nucleospin kits 


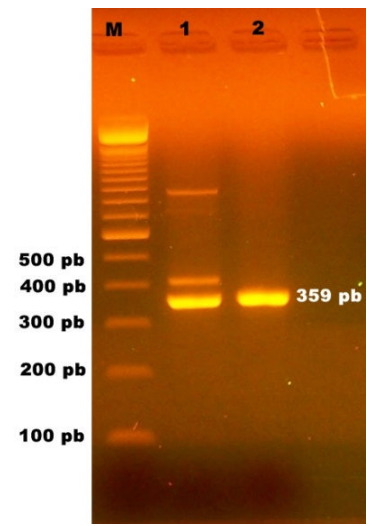

Fig 2. Electrophoresis of PCR product. (1) DNA marker, (2) Chicken nugget (MB), (3) Pork nugget

booklet with a minor modification. Sample of $200 \mathrm{mg}$ of nugget were homogenized by using a pestle and mortar under liquid nitrogen. The homogenized sample were mixed Buffer CF $65{ }^{\circ} \mathrm{C}$. The extraction was then performed by incubation of the mixture at room temperature $24 \mathrm{~h}$ after adding of Proteinase K. The next stages of extraction were carried out by following the procedures in the kit exactly according to kits booklet. The isolated DNA was analyzed by agarose gel electrophoresis $1 \%$ and checks its purity and concentration by means of UV spectrophotometer.

\section{Amplification of cytB DNA fragment using PCR}

Amplification process was started by adding approximately $100 \mathrm{ng}$ isolated DNA accompanied by 10 pmole of each forward (PF) and (PR) reverse primer to Ready-to-goPCR beads tube. The mixture was then added by $\mathrm{H}_{2} \mathrm{O}$ tube and mixed by gentle flicking followed by vortex and short spin centrifugation. The PCR tubes were then put into thermalcycler machine and programmed for predenaturation at $95{ }^{\circ} \mathrm{C}$ for $5 \mathrm{~min}$, 30 cycles of chain reaction using the following condition: denaturation at $95{ }^{\circ} \mathrm{C}$ for $1 \mathrm{~min}$, annealing at $55^{\circ} \mathrm{C}$ for $1 \mathrm{~min}$ and extension at $72{ }^{\circ} \mathrm{C}$ for $1 \mathrm{~min}$, followed by post extension step at $72{ }^{\circ} \mathrm{C}$ for $5 \mathrm{~min}$. The PCR product was analyzed with agarose gel electrophoresis and estimated its concentration by means of UV spectrophotometer to predict volume of PCR product needed for RFLP.

\section{RFLP by digestion with BseDI and BamHI}

For BamHI digestion, approximately $0.5 \mathrm{ng}$ PCR fragment was used. The digestion was started by mixing PCR fragment with $2 \mu \mathrm{L}$ BamHI buffer 10x, $20 \mathrm{U}$ of $B a m H I$ enzyme and added with nuclease free water to final volume $20 \mu \mathrm{L}$. The mixture was incubated at $37^{\circ} \mathrm{C}$ for $24 \mathrm{~h}$. The same amount $(0.5 \mathrm{ng})$ of PCR fragment was used for BseDI digestion. The PCR fragment was then mixed with $2 \mu \mathrm{L}$ BseDI buffer 10x, $20 \mathrm{U}$ of BseDI enzyme and added with nuclease free water to final

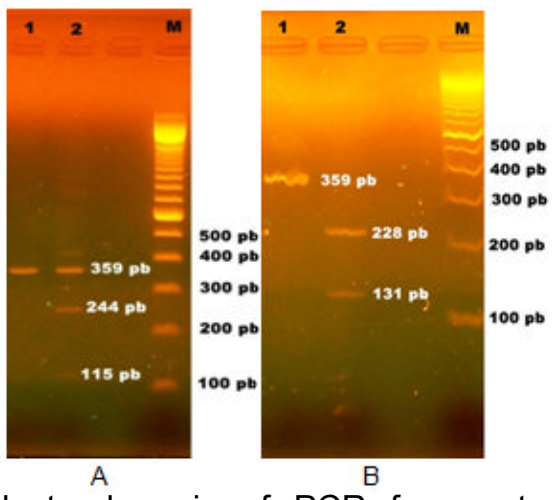

Fig 3. Electrophoresis of $P C R$ fragments digestion using BamHI (A) and BseDI (B). M = DNA marker, (1) Chicken nugget (2) Pork nugget

volume $20 \mu \mathrm{L}$. The mixture was incubated at $55{ }^{\circ} \mathrm{C}$ for $24 \mathrm{~h}$. After incubation, both mixtures form both digestion processes were then analyzed using $2 \%$ agarose gel electrophoresis.

\section{Method validation}

Specificity of the method was investigated by comparing the testing result of nugget containing pork with free porcine nugget. Limit of detection was performed by testing series of nugget with various concentration of pork 1, 2, 5, 10, 15, 20, 25 and 50\%. The lowest concentration of the pork in nugget in which test result still gave positive result was claimed as limit of detection. These repeat processes were also used to see precision of the method. The method was also applied to test commercial nugget. Four brand of Halallabeled commercial nugget as well as four brand of non labeled one were tested using the method.

\section{RESULT AND DISCUSSION}

\section{Specificity of the Method}

Specificity of the method was tested using $100 \%$ chicken nugget as a negative control and $100 \%$ pork nugget as a positive control. The method will be concluded as a specific if no interference in the RFLP results (244 and $115 \mathrm{bp}$ for $\mathrm{BamHI}$ and the 228 and $131 \mathrm{bp}$ for BseDI) that will only appear on positive control.

The electrophoresis analysis of PCR amplification of both positive and negative control can be seen in Fig. 2. Both sample show DNA fragments with size of approximately $359 \mathrm{bp}$ as dominant PCR product. It means that PCR succeed to amplify part of cytB gene both in chicken and pork. Although the size of the fragments in both samples is same, they have different nucleotide sequenced. Meanwhile the electrophoresis of digestion product of PCR fragment with digestion 


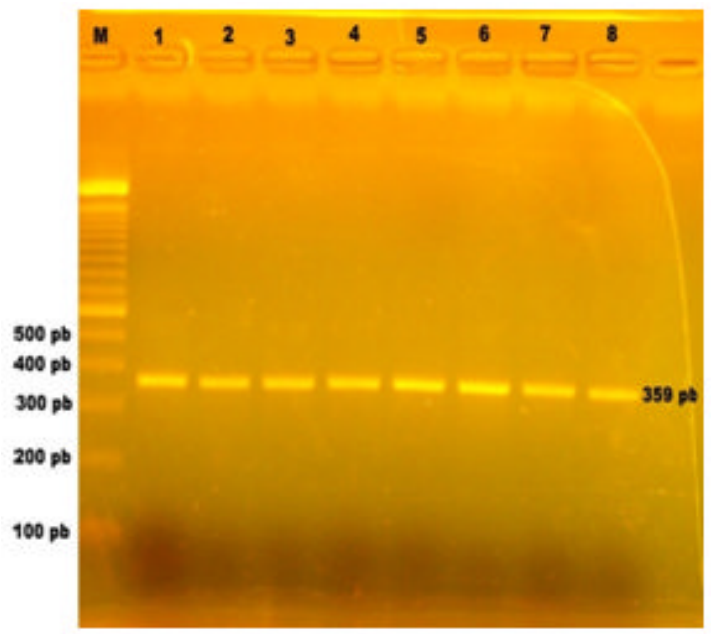

Fig 4. Electrophoresis of $P C R$ product of chicken nugget with various pork content. (M) DNA Marker, (1) Negative control (chicken nugget-CN), (2) CN-1\%Pork (3) $\mathrm{CN}-2 \%$ Pork, (4) CN-5\%Pork, (5) CN-10\%Pork, (6) CN-25\%Pork, (7) CN-50\%Pork, (8) Positive control (Pork nugget)

enzymes can be seen in Fig. 3. The result shows that typical restriction fragments which theoretically related to the presence of pig cytB results (244 and $115 \mathrm{bp}$ for $\mathrm{BamHI}$ and the 228 and $131 \mathrm{bp}$ for BseDI) only observed in pork nugget. Based on this result, it is confirmed that the method is specific to differentiate chicken nugget from pork nugget. The result in line with our previous result with meatball sample [25].

\section{Limit of Detection (LOD)}

The LOD determination was purposed to check how low the pork content in nugget can be detected by the method. LOD was by performing the method to the chicken nugget sample which containing pork in various concentrations.

PCR of isolated DNA of chicken nugget with various pork contents result in same fragment with size of approximately $359 \mathrm{bp}$, as shown at Fig. 4. RFLP analysis using restriction enzymes of the PCR fragment, as shown at Fig. 5, gives no typical pig cytB fragment for negative control (chicken nugget). However, in positive control and chicken nugget containing pork, it was observed restriction fragment typical pig cytB fragment. The pig RFLP fragment can be clearly seen in the sample which contains pork. The restriction patterns still consist of fragment with the size of $359 \mathrm{bp}$. It is because the PCR fragment is a mixture of cytB gene fragment of chicken and pork. The fragment of cytB of chicken is remained uncut and present as $359 \mathrm{bp}$ fragment. The typical pig RFLP fragment can be seen in the sample of nugget containing pork as low as 5\% (Fig. 5). In other

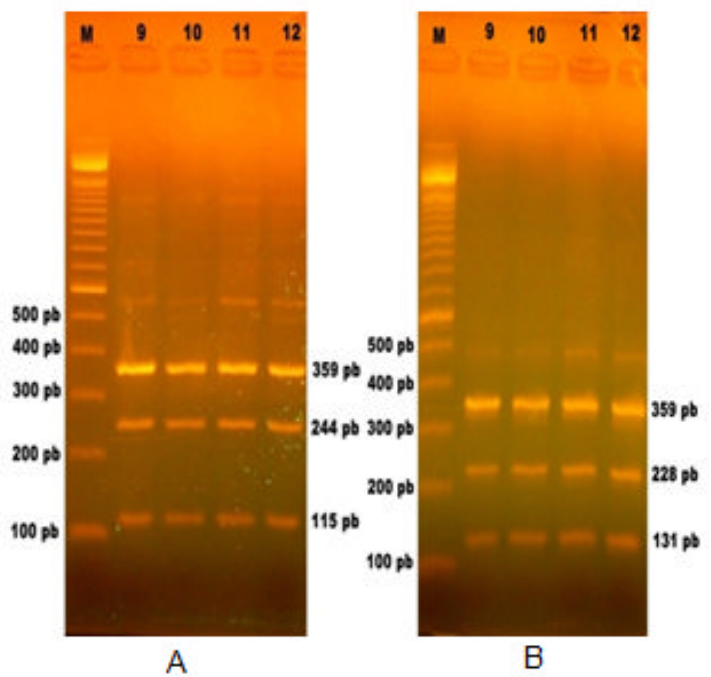

Fig 5. Electrophoresis of $P C R$ fragment digestion using $\mathrm{BamHI}$ (A) and BseDI (B). M = DNA marker, (9) CN-5\%Pork, (10) CN-10\%Pork, (11) CN-25\%Pork, (12) CN-50\%Pork. (The result of negative test is not shown)

words LOD of the method is $5 \%$. This value of percentage is relatively high for limit of detection. This LOD is also higher than previous report for meatball in which this method could detect up to $1 \%$ pork content [25]. However this value is still acceptable due the fact that in production of nugget mixing of the pork to the chicken is purposed to reduce the cost of production, by substituting chicken with pork. Therefore the amount of pork to be added to substitute chicken must be higher than $5 \%$. For meatball analysis lower LOD is needed due to the application of pork in meatball is not only to substitute the beef but also to improve the taste in soup as well in meatball itself, therefore small amount of pork is enough. The high value of LOD in nugget than meatball could also due to the shape nugget is much coarser than meatball leading to nugget less homogeneous than meatball. The use of eggs in this process will lead to interference because the egg is also containing chicken mtDNA, although in positive control sometimes we can see incomplete enzyme digestion of PCR fragment (Fig. 3A).

\section{Application of the Method to the Commercial Chicken Nugget}

Eight sample of chicken nugget was selected from the supermarkets. Four of the samples, SM1SM4, are Halal labeled while the others, SM5-SM8 are without Halal label. PCR result and RFLP analysis of the samples are shown at Fig. 6 and 7, respectively. Based on the result it can be concluded that none of the samples were contaminated by pork, both in group 


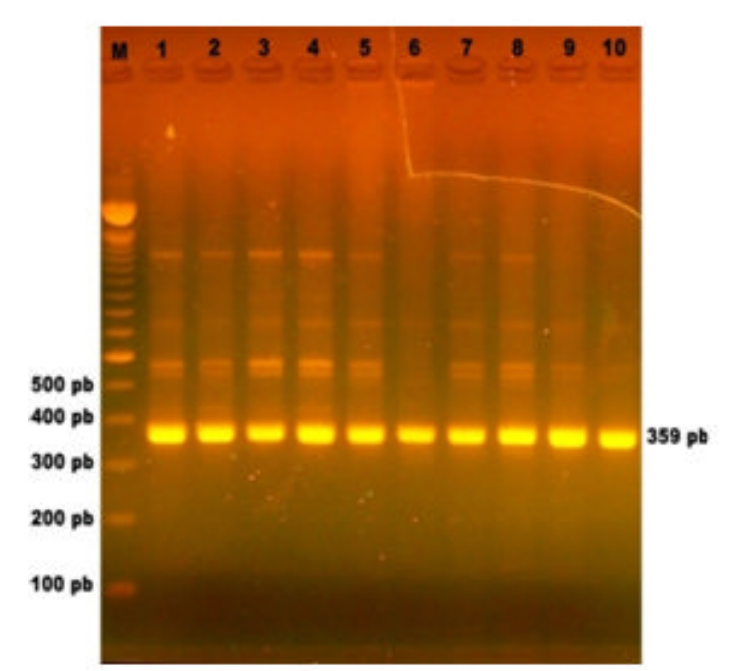

Fig 6. Electrophoresis of PCR product of commercial nugget and the control: (1) SM1 (2) SM2 (3) SM3 (4) SM4 (5) SM5 (6) SM6 (7) SM7 (8) SM8 (9) Negative control (Chicken nugget) (10) Positive control (Pork nugget)

of Halal labeled as well as non labeled one. The result also indicates that Halal certification process, which is requirement prior labeling, of the chicken nugget has worked properly to guarantee of the Halal status of the chicken nugget.

\section{CONCLUSION}

PCR-RFLP of $c y t B$ gene analysis employing BseDI and BamHI restriction enzymes could be specifically used to detect pork contamination in chicken nugget. The method could detect up to $5 \%$ contamination which acceptable for nugget sample. The method has also been applied to test sample of commercial chicken nugget result in no contamination in both Halal labeled and non-labeled nugget.

\section{ACKNOWLEDGEMENT}

This work was financially supported by LPPT UGM, scheme of multidisciplinary research, 2011 annual budget (RKAT 2011).

\section{REFERENCES}

1. Lai, Y.W., Kemsley, E.K., and Wilson, R.H., 1995, Food Chem., 53, 1, 95-98.

2. Al-Jowder, O., Kemsley, E.K., and Wilson, R.H. 1997, Food Chem., 59, 2, 195-201.

3. Poulli, K.I., Mousdis, G.A., and Georgiou, C.A., 2007, Food Chem., 105, 1, 369-375.

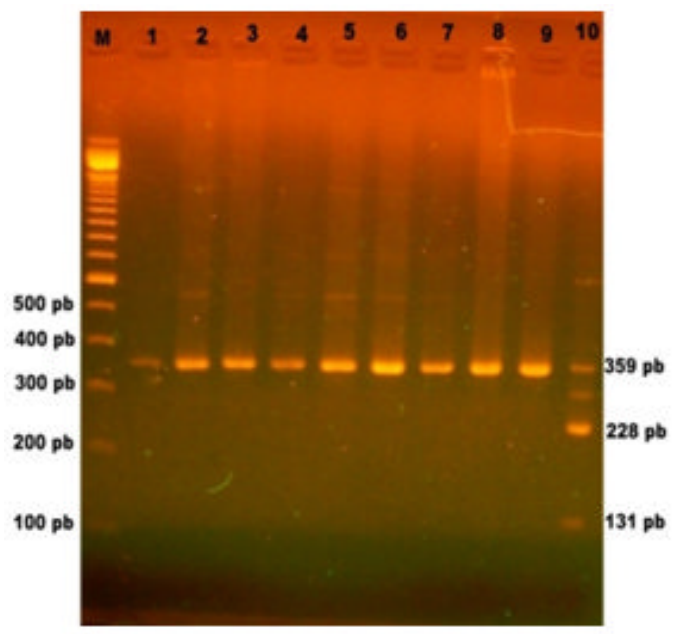

Fig 7. Electrophoresis of digestion of PCR product of commercial nugget with BseDI. M: DNA marker, (1) Negative control (2) SM1, (3) SM2, (4) SM3, (5) SM4, (6) SM5, (7) SM6, (8) SM7, (9) SM8, (10) Positive control. The digestion with BamHI gave same result and the picture is not shown

4. Jones, J.L., 1991, Trends Food Sci. Technol., 2, 28-32.

5. Meyer, R., and Candrian, U., 1996, Lebens. Wiss. Technol., 29, 1, 1-9.

6. Craig, A., Ritchie, A.H. and Mackie, N., 1995, Food Chem., 52, 4, 451-454.

7. King, N.L, and Kurth, L., 1982, J. Food Sci., 47, 5, 1608-1612.

8. Chen, F.C., and Hseih, Y.H., 2000, J. AOAC Int., 83, 1, 79-85.

9. Schönherr, J., 2002, J. Agric. Food Chem., 50, 7, 1945-1950.

10. Ghovatti, S., Nassiri, M.R., Mirhoseini, S.Z., Moussavi, A.H., and Javadmanesh, A., 2009, Food Control, 20, 8, 696-699.

11. Ebbehøj, K.F., and Thomsen, P.D., 1991, Meat Sci., 30, 4, 359-366.

12. Calvo, J.H., Zaragoza, P., and Osta, R., 2001, J. Anim. Sci., 79, 8, 2108-2112.

13. Fajardo, V., González, I., López-Calleja, I., Martin, I., Hernández, P.E., García, T., and Martin, R., 2006, J. Agric. Food Chem., 54, 4, 1144-1150.

14. Girish, P.S., Anjaneyulu, A.S.R., Viswas, K.N., Shivakumar, B.M., Anand, M., Patel, M., and Sharma, B., 2005, Meat Sci., 70, 1, 107-112.

15. Ahmed, M.M.M., Abdel-Rahman, S.M., and ElHanafy, A.A., 2007, Biotechnology, 6, 3, 426-430.

16. Aida, A.A., Che-Man, Y.B., Wong, C.M.V.L., Raha, A.R., and Son, R., 2005, Meat Sci., 69, 1, 47-52.

17. Khairalla, K.M.S., Hago, B.E., Hassan, T., Majid, A.A., Dafalla, E-A., Karrar, A.E., and Aradaib, I.E., 2005, Pak. J. Biol. Sci., 8, 3, 501-504. 
18. Che Man, Y.B., Aida, A.A., Raha, A.R., and Son, R., 2007, Food Control, 18, 7, 885-889.

19. Sawyer, J., Wood, C., Shanahan, D., Gout, S., and McDowell, D., 2003, Food Control, 14, 8, 579-583.

20. Tanabe, S., Hase, M., Yano, T., Sato, M., Fujimura, T., and Akiyama, H., 2007, Biosci. Biotechnol. Biochem., 71, 12, 3131-3135.

21. Saez, R.Y.S., and Toldra, F., 2004, Meat Sci., 66, 3, $659-665$.

22. Dalmasso, A., Fontanella, E., Piatti, P., Civera, T., Rosati, S., and Bottero, M., 2004, Mol. Cell. Probes, 18, 2, 81-87.
23. Bottero, M.T., Dalmasso A., Nucera, D., Turi, R.M., Rosati, S., Squadrone, S., Goria, M., and Civera, T., 2003, J. Food Prot., 66, 12, 2307-2312.

24. Walker, J.A., Hughes, D.A., Anders, B.A., Shewale, J., Sinha, S.K., and Batzer, M.A., 2003, Anal. Biochem., 316, 2, 259-269.

25. Raharjo, T.J. and Sismindari, 2010, Validation of RFLP-Combined PCR Technique to Detect Porcine Contamination in Meatball (Halal Analysis), Proceed. $2^{\text {nd }}$ ICCS, Department of Chemistry Universitas Gadjah Mada, Yogyakarta 14-15 October 2010. 